\title{
THE ULTRAFILTRABILITY OF POTASSIUM AND SODIUM IN HUMAN SERUM
}

\author{
BY ROBERT TARAIL, 1 ELAINE S. HACKER, ${ }^{2}$ AND ROBERT TAYMOR \\ (From the Department of Biochemistry, Boston University School of Medicine and Fifth and \\ Sixth Medical Services [Boston University], Boston City Hospital, Boston, Mass.)
}

(Submitted for publication August 20, 1951; accepted October 1, 1951)

One of the puzzling clinical aspects of the metabolism of electrolytes is the genesis of symptoms and signs of potassium depletion and potassium intoxication (1-3). Precipitous flaccid paralysis, sensory disturbances and respiratory failure, altogether analogous to the sequence of events in familial periodic paralysis, may occur in these disturbances of potassium metabolism characterized by either deficit or plethora of the ion. The preponderance of evidence indicates that such gross clinical derangements are observed in but a minority of instances of abnormality in the metabolism of potassium (1-9). Review of existing data, furthermore, fails to disclose a clinical, chemical, or physiologic difference which could account for the capricious incidence of serious manifestations in this minority of patients.

The extensive metabolic studies of Jantz (10) in nine cases of familial periodic paralysis seem to afford a clue to the solution of this problem. He found that episodes of paralysis could be consistently related to a profound reduction in the ultrafiltrable fraction of plasma potassium. Although this finding has not been confirmed or negated, such an explanation might in part account for paralytic phenomena which occasionally supervene in patients without familial periodic paralysis, who develop disturbances of potassium metabalism.

The present investigation comprises an analysis of the diffusibility in vitro of potassium and sodium of sera obtained from a group of normal subjects and an analogous preliminary survey of patients with derangements of electrolyte metabolism.

\footnotetext{
1 Present address: Department of Research Medicine, University of Pittsburgh School of Medicine, Pittsburgh 13, Pa.

2 Part of the data upon which this report is based is taken from a thesis submitted to the Graduate School of Boston University by E. S. H. in partial fulfillment of the requirements for the degree of Master of Arts.
}

\section{METHODS AND MATERIALS}

The normal subjects were 24 medical students of the freshman class of Boston University School of Medicine. Patients in various states of electrolyte imbalance and dehydration were studied from the wards of Boston City Hospital. Normal subjects came to the laboratory following an overnight fast. Blood was withdrawn, using minimal stasis, under mineral oil, and serum was separated anaerobically within one hour of clot formation. A portion of serum from the centrifuged blood was aspirated from beneath its thin protective coat of oil into Lavietes' ultrafiltration chambers ${ }^{3}$ (11). Anaerobic ultrafiltration transpired through cellophane membranes at room temperature for about 48 hours. Technical details and equipment were identical with those described by Lavietes (11). Both original serum and ultrafiltrate were analyzed simultaneously. Serum residue was not analyzed.

Sodium and potassium were determined on the Barclay flame photometer using lithium as the internal standard (12). All fluids were analyzed in duplicate-i.e., two separate dilutions of 1 to 50 and 1 to 100 for potassium and 1 to 200 and 1 to 400 for sodium. Each unknown solution was "bracketed" by two knowns, and serum and corresponding ultrafiltrate were read together. Final values were averages of the results of two or more readings of each unknown solution. Average readings of duplicate dilutions were within $2 \%$ of one another. Before each group of determinations, the accuracy and precision of the instrument were further verified by analyzing samples of "artificial serum"-a carefully compounded known solution of salts of potassium, sodium, calcium, and magnesium in such proportion that concentrations of these cations were within the range of normal human blood serum.

Water of serum and ultrafiltrate was estimated by the method of Eisenmann, Mackenzie, and Peters (13). In a minority of instances insufficient quantities of ultrafiltrate were available, so that the water content was assumed to be that of the arithmetic mean of the series of ultrafiltrates actually analyzed. Distribution ratios of potassium and sodium are expressed as quotients of their concentrations in water of ultrafiltrate divided by concentration in water of serum.

Conventional methods of statistical analyses, as described by Mainland (14), were utilized.

3 Obtained through the courtesy of F. Pierce Noble, 110 Benham Street, New Haven, Connecticut. 


\section{RESULTS}

Chemical data and diagnoses are presented in Tables I and II.

The ranges of serum potassium and sodium values in the group of 24 normal subjects are 3.82 to 4.49 meq./1. and 139.8 to 148.9 meq./1., respectively (Table I). The means were $4.16 \pm 0.22$ meq. $/ 1.4$ for potassium and $142.5 \pm 2.0$ meq./1. for sodium. With respect to the upper limit of the sodium range, it should be noted that only one result exceeded 144.8; that value (148.9) deviated from the mean by more than three standard deviations and may therefore be considered anomalous, at least from the statistical standpoint.

The average distribution ratios of electrolytes in water of ultrafiltrate and serum, in 16 normal subjects (Table I), are $0.943 \pm 0.009$ for potassium and $0.942 \pm 0.007$ for sodium. Their ranges were 0.926 to 0.957 , and 0.929 to 0.954 , respectively.

4 Unless otherwise stated, the plus or minus figure following the mean refers to standard deviation.
The ultrafiltrability of sodium and of potassium under the conditions of these experiments was therefore nearly identical.

Distribution ratios during 19 evaluations in a series of ten patients (Table II) in whom concentrations of serum potassium and sodium varied tremendously were strikingly similar to those observed in the control group; the patients displayed either potential or definite and flagrant disturbances of electrolyte and water metabolism. Mean ratios of $0.939 \pm 0.043$ in the case of potassium and $0.944 \pm 0.046$ for sodium were almost indistinguishable from their counterparts in normal subjects. The ranges of 0.909 to $0.960(\mathrm{~K})$ and 0.920 to $0.966(\mathrm{Na})$ were, however, wider than the corresponding values in the group of normal subjects. A greater degree of variability is likewise evident as defined by the larger standard deviations. It appears clear, nevertheless, that the diffusibility of both potassium and sodium in these patients did not differ significantly from that of the normal group.

TABLE I

The distribution of sodium and potassium between serum and in vitro ultrafiltrate of serum in normal subjects

\begin{tabular}{|c|c|c|c|c|c|c|c|c|c|c|c|c|}
\hline \multirow{2}{*}{ Subj., age } & \multicolumn{2}{|c|}{ Serum } & \multicolumn{2}{|c|}{ Ultrafilt. } & \multicolumn{2}{|c|}{ Water } & \multirow{2}{*}{$(\mathrm{K}) \mathrm{u}^{*}$} & \multirow{2}{*}{$(\mathrm{Na}) \mathrm{u}^{*}$} & \multirow{2}{*}{$(\mathrm{K}) \mathrm{s}^{*}$} & \multirow{2}{*}{$(\mathrm{Na}) 8^{*}$} & \multirow{2}{*}{$\frac{(\mathbf{K}) \mathbf{u}}{(\mathbf{K}) \mathbf{s}}$} & \multirow{2}{*}{$\frac{(\mathrm{Na}) \mathrm{u}}{(\mathrm{Na}) \mathrm{s}}$} \\
\hline & $\mathbf{K}$ & $\mathrm{Na}$ & $\mathbf{K}$ & $\mathrm{Na}$ & Ser. & Uit. & & & & & & \\
\hline $\begin{array}{ll}\text { H. C. } & 25 \\
\text { C. F. } & 24 \\
\text { H. S. } & 21 \\
\text { A. B. } & 20 \\
\text { M. H. } & 24 \\
\text { J. L. } & 26 \\
\text { J. M. } & 24 \\
\text { H. W. } & 21 \\
\text { M. B. } & 22 \\
\text { R. O. } & 30 \\
\text { M. B. } & 22 \\
\text { D. W. } & 27 \\
\text { N. W. } & 21 \\
\text { C. P. } & 29 \\
\text { T. L. } & 27 \\
\text { A. K. } & 25 \\
\text { M. D. } & 24 \\
\text { Z. L. } & 24 \\
\text { G. H. } & 22 \\
\text { A. R. } & 24 \\
\text { S. F. } & 26 \\
\text { H. L. } & 24 \\
\text { P. L. } & 25 \\
\text { M. A. } & 29 \\
\text { Mean } & \\
\text { St. dev. } & \\
\text { St. error } & \end{array}$ & $\begin{array}{c}\text { meq./l. } \\
3.93 \\
4.35 \\
4.49 \\
4.18 \\
4.43 \\
4.27 \\
4.11 \\
4.04 \\
4.25 \\
3.90 \\
4.35 \\
4.06 \\
3.92 \\
4.39 \\
4.14 \\
4.11 \\
4.49 \\
4.37 \\
3.82 \\
3.82 \\
4.11 \\
3.91 \\
4.45 \\
4.06 \\
4.16 \\
0.22 \\
0.05\end{array}$ & $\begin{array}{r}\text { meq./l. } \\
142.2 \\
140.9 \\
142.3 \\
142.7 \\
148.9 \\
142.8 \\
139.8 \\
142.0 \\
144.8 \\
144.7 \\
142.4 \\
142.9 \\
143.4 \\
141.8 \\
142.9 \\
140.1 \\
144.0 \\
142.3 \\
140.2 \\
142.8 \\
139.8 \\
143.1 \\
141.7 \\
140.3 \\
142.5 \\
2.0 \\
0.4\end{array}$ & $\begin{array}{c}\text { meq./l. } \\
4.01 \\
4.39 \\
4.45 \\
4.13 \\
4.48 \\
4.28 \\
4.13 \\
4.03 \\
4.32 \\
3.87 \\
4.38 \\
4.12 \\
3.93 \\
4.43 \\
4.19 \\
4.14\end{array}$ & $\begin{array}{c}\text { meq./l. } \\
142.2 \\
142.7 \\
141.9 \\
143.7 \\
148.5 \\
143.5 \\
140.8 \\
143.2 \\
145.6 \\
145.7 \\
142.4 \\
143.1 \\
144.6 \\
142.9 \\
144.9 \\
140.5\end{array}$ & $\begin{array}{c}\text { gms./l. } \\
933 \\
937 \\
930 \\
933 \\
926 \\
933 \\
928 \\
932 \\
933 \\
936 \\
931 \\
931 \\
932 \\
930 \\
932 \\
936 \\
927 \\
929 \\
935 \\
928 \\
932 \\
927 \\
931 \\
930\end{array}$ & $\begin{array}{l}996 \\
994 \\
992 \\
996 \\
\\
994 \\
993 \\
995 \\
992 \\
994 \\
996\end{array}$ & $\begin{array}{c}\text { meq./l. } \\
4.03 \\
4.42 \\
4.48 \\
4.15 \\
4.51 \\
4.30 \\
4.16 \\
4.06 \\
4.34 \\
3.89 \\
4.41 \\
4.15 \\
3.95 \\
4.46 \\
4.22 \\
4.16\end{array}$ & $\begin{array}{c}\text { meq./l. } \\
143.0 \\
143.5 \\
142.7 \\
144.5 \\
149.4 \\
144.1 \\
141.7 \\
144.4 \\
146.1 \\
146.5 \\
143.2 \\
144.0 \\
145.3 \\
144.0 \\
145.7 \\
141.0\end{array}$ & $\begin{array}{c}\text { meg./l. } \\
4.21 \\
4.64 \\
4.83 \\
4.48 \\
4.79 \\
4.58 \\
4.43 \\
4.33 \\
4.55 \\
4.17 \\
4.67 \\
4.36 \\
4.21 \\
4.72 \\
4.44 \\
4.39 \\
4.84 \\
4.71 \\
4.09 \\
4.12 \\
4.41 \\
4.22 \\
4.78 \\
4.37\end{array}$ & $\begin{array}{c}\text { meg. } . \\
152.4 \\
150.4 \\
153.2 \\
152.9 \\
160.9 \\
153.0 \\
150.6 \\
152.3 \\
155.1 \\
154.6 \\
153.0 \\
153.5 \\
153.8 \\
152.4 \\
153.4 \\
149.7 \\
155.3 \\
153.3 \\
149.9 \\
153.8 \\
150.0 \\
154.4 \\
152.2 \\
150.9\end{array}$ & $\begin{array}{l}0.957 \\
0.953 \\
0.928 \\
0.926 \\
0.942 \\
0.939 \\
0.939 \\
0.938 \\
0.954 \\
0.933 \\
0.944 \\
0.952 \\
0.938 \\
0.945 \\
0.950 \\
0.948\end{array}$ & $\begin{array}{l}0.938 \\
0.954 \\
0.931 \\
0.945 \\
0.929 \\
0.942 \\
0.941 \\
0.948 \\
0.942 \\
0.948 \\
0.936 \\
.0 .938 \\
0.945 \\
0.945 \\
0.950 \\
0.942\end{array}$ \\
\hline
\end{tabular}

* These concentrations of potassium and sodium have been corrected for water content of ultrafiltrate and of serum by using analytical data or, in the case of certain ultrafiltrates, mean values of other analyses ( $c f$. Methods). 
TABLE II

The distribution of sodium and potassium between serum and in vitro ultrafiltrate of serum in patients with disturbances of electrolyte metabolism

\begin{tabular}{|c|c|c|c|c|c|c|c|c|c|c|c|c|c|}
\hline \multirow{2}{*}{ Pt. } & \multirow{2}{*}{ Remarks } & \multicolumn{2}{|c|}{ Serum } & \multicolumn{2}{|c|}{ Ultrafilt. } & \multicolumn{2}{|c|}{ Water } & \multirow{2}{*}{$(\mathrm{K}) \mathrm{u}^{*}$} & \multirow{2}{*}{$(\mathrm{Na}) \mathrm{u}^{*}$} & \multirow{2}{*}{$(\mathrm{K}) \mathrm{s}^{*}$} & \multirow{2}{*}{$(\mathrm{Na}) \mathrm{s}^{*}$} & \multirow{2}{*}{$\frac{(\mathrm{K}) \mathrm{u}}{(\mathrm{K}) \mathbf{s}}$} & \multirow{2}{*}{$\frac{(\mathrm{Na}) \mathrm{u}}{(\mathrm{Na}) \mathrm{s}}$} \\
\hline & & $\mathbf{K}$ & $\mathrm{Na}$ & $\mathbf{K}$ & $\mathrm{Na}$ & Ser. & Ult. & & & & & & \\
\hline $\begin{array}{l}\text { B. } \\
\text { T. } \\
\text { H. } \\
\text { S. } \\
\text { T. } \\
\text { R. } \\
\text { K. } \\
\text { S. } \\
\text { M. } \\
\text { L. }\end{array}$ & $\begin{array}{l}\text { Renal insufficiency } \\
\text { Diabetes mellitus } \\
\text { Diabetes mellitus } \\
\text { Myocardial infarction } \\
\text { Diabetic acidosis } \\
\text { Renal insufficiency } \\
\text { Renal and hepatic } \\
\quad \text { insufficiency } \\
\text { Diabetic acidosis } \\
\text { Intestinal obstruction } \\
\text { Renal insufficiency }\end{array}$ & $\begin{array}{c}\text { meq./l. } \\
4.51 \\
4.27 \\
6.20 \\
5.69 \\
5.87 \\
3.20 \\
3.25 \\
3.16 \\
4.46 \\
4.07 \\
4.51 \\
4.91 \\
2.37 \\
2.50 \\
2.89 \\
7.75 \\
7.92 \\
8.47 \\
9.13\end{array}$ & $\begin{array}{l}\text { meq./l. } \\
144.4 \\
144.1 \\
141.6 \\
144.2 \\
143.8 \\
123.9 \\
130.1 \\
131.5 \\
132.2 \\
132.2 \\
124.5 \\
136.3 \\
131.5 \\
135.4 \\
117.3 \\
117.1 \\
120.1 \\
115.6\end{array}$ & \begin{tabular}{|c|} 
meq./l. \\
4.40 \\
4.25 \\
6.20 \\
5.69 \\
6.04 \\
3.19 \\
3.25 \\
3.07 \\
4.32 \\
4.04 \\
4.52 \\
5.07 \\
2.35 \\
2.50 \\
2.80 \\
7.80 \\
7.99 \\
8.37 \\
9.22
\end{tabular} & \begin{tabular}{|c} 
meq./l. \\
143.6 \\
144.8 \\
141.2 \\
144.9 \\
146.2 \\
120.6 \\
129.0 \\
129.3 \\
132.0 \\
131.1 \\
129.5 \\
135.9 \\
132.5 \\
135.1 \\
118.3 \\
117.1 \\
122.0 \\
116.6
\end{tabular} & \begin{tabular}{|c} 
gms./l. \\
941 \\
927 \\
930 \\
934 \\
904 \\
923 \\
936 \\
934 \\
950 \\
945 \\
942 \\
919 \\
946 \\
948 \\
930 \\
929 \\
921 \\
933 \\
930
\end{tabular} & \begin{tabular}{|c|} 
gms. $/ l$. \\
994 \\
975 \\
\\
\\
987 \\
987 \\
999 \\
993 \\
989 \\
989 \\
988
\end{tabular} & \begin{tabular}{|c|} 
meq. $/ l$. \\
4.43 \\
4.36 \\
6.27 \\
5.75 \\
6.12 \\
3.23 \\
3.25 \\
3.09 \\
4.37 \\
4.08 \\
4.57 \\
5.13 \\
2.38 \\
2.53 \\
2.83 \\
7.89 \\
8.08 \\
8.46 \\
9.32
\end{tabular} & $\begin{array}{l}\text { meq./l. } \\
144.5 \\
148.5 \\
142.8 \\
146.8 \\
148.1 \\
120.7 \\
129.9 \\
130.7 \\
133.5 \\
132.7 \\
130.9 \\
137.4 \\
134.0 \\
136.6 \\
119.6 \\
118.4 \\
123.4 \\
117.9\end{array}$ & $\begin{array}{c}\text { meq./l. } \\
4.79 \\
4.61 \\
6.67 \\
6.09 \\
6.50 \\
3.47 \\
3.47 \\
3.38 \\
4.69 \\
4.31 \\
4.79 \\
5.34 \\
2.51 \\
2.64 \\
3.11 \\
8.34 \\
8.60 \\
9.08 \\
9.82\end{array}$ & \begin{tabular}{|c|} 
meq./l. \\
153.5 \\
155.4 \\
152.3 \\
159.5 \\
155.8 \\
132.4 \\
139.3 \\
138.4 \\
139.9 \\
140.3 \\
135.5 \\
144.1 \\
138.7 \\
145.6 \\
126.3 \\
127.1 \\
128.7 \\
124.3
\end{tabular} & $\begin{array}{l}0.925 \\
0.946 \\
0.940 \\
0.944 \\
0.942 \\
0.931 \\
0.936 \\
0.914 \\
0.931 \\
0.946 \\
0.954 \\
0.960 \\
0.948 \\
0.958 \\
0.909 \\
0.946 \\
0.939 \\
0.931 \\
0.949 \\
\\
0.939 \\
0.043 \\
0.010\end{array}$ & $\begin{array}{l}0.941 \\
0.956 \\
0.938 \\
\\
0.920 \\
0.951 \\
0.911 \\
0.932 \\
0.944 \\
0.954 \\
0.945 \\
0.966 \\
0.954 \\
0.966 \\
0.938 \\
0.947 \\
0.932 \\
0.959 \\
0.949 \\
\\
0.944 \\
0.046 \\
0.013\end{array}$ \\
\hline
\end{tabular}

* These concentrations of potassium and sodium have been corrected for water content of ultrafiltrate and of serum by using analytical data or, in the case of certain ultrafiltrates, mean values of other analyses (cf. Methods).

\section{DISCUSSION}

Concentrations of serum potassium and sodium in the present series of normal subjects are in reasonable agreement with certain previously reported series $(12,15)$. Distribution ratios of potassium and sodium in serum of these subjects corresponded very closely to predictions of the Gibbs-Donnan equilibrium (16). This ratio in the case of sodium coincides almost exactly with mean values already reported in man and other animals (17-23). The distribution coefficient of potassium approximated that found in work on dogs (20) and in recent studies of Folk, Zierler, and Lilienthal (23) as well as of Berliner, Kennedy, and Hilton (24). Such distribution ratios of sodium and potassium confirm the assumption usually made with respect to concentrations of the ions in extracellular fluid in relation to certain balance calculations $(4,25)$.

Distribution ratios of potassium ascertained by earlier investigators were, in the vast majority of instances, below 0.90 . Although the explanation for this disparity is unclear, certain of the follow- ing factors may well have been involved: unreliability of earlier analytical methods for determination of potassium; failure to adhere to the excellent methodologic criteria and precautions pertaining to ultrafiltration studies outlined by Ingraham, Lombard, and Visscher and implemented by Lavietes $(21,11)$; differences in technique of ultrafiltration including study of in vivo, rather than in vitro, transudates; species differences. Finally, the range of variation of the distribution ratios of both sodium and potassium in the present group of normal individuals is considerably less than has been found by previous investigators.

No specific or definite symptoms or signs which could be clearly ascribed to abnormalities in potassium metabolism were observed in these patients. Whether paralysis and related disturbances occur only when abnormal binding of potassium, presumably to protein, supervenes cannot therefore be gleaned from the present study. Search for suitable patients with neuromuscular abnormalities definitely attributable to abnormal metabolism of potassium continues. Although the occasional occurrence of this correlation appears to be incon- 
trovertible, its rarity is documented by the fact that we have not observed it during the observation and study, over several years, of many patients with potassium deficiency and intoxication.

\section{SUM MARY}

1. The diffusibility of serum potassium and sodium was measured in vitro, using Lavietes' technique, in a group of normal subjects and in a series of patients with latent or striking disturbances in the metabolism of electrolytes.

2. The mean concentrations of serum sodium and potassium in 24 medical students were 142.5 \pm 2.0 meq. $/ 1$. and $4.16 \pm 0.22$ meq. $/ 1$., respectively, The average distribution ratios of potassium and sodium expressed as the quotient of concentration in water of ultrafiltrate divided by concentration in water of serum were $0.943 \pm 0.009$ and $0.942 \pm$ 0.007 .

3. Despite impressive differences in total concentration of potassium and sodium in 16 studies of ten patients, their ultrafiltrable fractions did not appear to differ significantly from those of the normal series.

4. Implications of these findings for certain clinical aspects of the metabolism of potassium are discussed.

\section{REFERENCES}

1. Finch, C. A., Sawyer, C. G., and Flynn, J. M., The clinical syndrome of potassium intoxication. Am. J. Med., 1946, 1, 337.

2. Danowski, T. S., Newer concepts of the role of potassium in disease. Am. J. Med., 1949, 7, 525.

3. Elkinton, J. R., and Tarail, R., The present status of potassium therapy. Am. J. Med., 1950, 9, 200.

4. Darrow, D. C., The retention of electrolyte during recovery from severe dehydration due to diarrhea. J. Pediat., 1946, $28,515$.

5. Tarail, R., and Elkinton, J. R., Potassium deficiency and the role of the kidney in its production. J. Clin. Invest., 1949, 28, 99.

6. Greenman, L., Mateer, F. M., Gow, 'R. C., Peters, J. H., and Danowski, T. S., Some observations on the development of hypokaliemia during therapy of diabetic acidosis in juvenile and young adult subjects. J. Clin. Invest., 1949, 28, 409.

7. Mateer, F. M., Greenman, L., Austin, A. C., Peters, J. H., Mermelstein, H., Weigand, F., and Danowski, T. S., The use of potassium chloride in the preoperative treatment of pyloric stenosis in infants. Am. J. M. Sc., 1951, 221, 21.

8. Elkinton, J. R., Tarail, R., and Peters, J. P., Trans- fers of potassium in renal insufficiency. J. Clin. Invest., 1949, 28, 378.

9. Merrill, J. P., Levine, H. D., Somerville, W., and Smith, S., Clinical recognition and treatment of acute potassium intoxication. Ann. Int. Med., 1950, 33, 797.

10. Jantz, H., Stoffwechseluntersuchungen bei paroxysmaler Lähmung. Nervenarzt, 1947, 18, 360.

11. Lavietes, P. H., Anaerobic ultrafiltration. J. Biol. Chem., 1937, 120, 267.

12. Wallace, W. M., Holliday, M., Cushman, M., and Elkinton, J. R., The application of the internal standard flame photometer to the analysis of biologic material. J. Lab. \& Clin. Med., 1951, 37, 621.

13. Eisenmann, A. J., Mackenzie, L. B., and Peters, J. P., Protein and water of serum and cells of human blood, with a note on the measurement of red blood cell volume. J. Biol. Chem., 1936, 116, 33.

14. Mainland, D., The Treatment of Clinical and Laboratory Data. Oliver \& Boyd, Edinburgh, 1938.

15. Hald, P. M., Notes on the determination and distribution of sodium and potassium in cells and serum of normal human blood. J. Biol. Chem., 1946, 163, 429.

16. Peters, J. P., Body Water: The Exchange of Fluids in Man. Charles C Thomas, Springfield, IIl., 1935.

17. Loeb, R. F., Atchley, D. W., and Palmer, W .W., On the equilibrium condition between blood serum and serous cavity fluids. J. Gen. Physiol., 1922, 4, 591.

18. Hastings, A. B., Salveson, H. A., Sendroy, J., and Van Slyke, D. D., Studies of gas and electrolyte equilibria in blood; distribution of electrolytes between transudates and serum. J. Gen. Physiol., $1927,8,701$.

19. Greene, C. H., and Power, M. H., The distribution of electrolytes between serum and the in vivo dialysate. J. Biol. Chem., 1931, 91, 183.

20. Greene, C. H., Bollman, J. L., Keith, N. M., and Wakefield, E. G., The distribution of electrolytes between serum and transudates. J. Biol. Chem., 1931, 91, 203.

21. Ingraham, R. C., Lombard, C., and Visscher, M. B., The characteristics of ultrafiltrates of plasma. J. Gen. Physiol., 1933, 16, 637.

22. Gilligan, D. R., Volk, M. C., and Blumgart, H. L., Observations on the chemical and physical relation between blood serum and other body fluids. I. The nature of edema fluids and evidence regarding the mechanism of edema formation. J. Clin. Invest., 1934, 13, 365.

23. Folk, B. P., Zierler, K. L., and Lilienthal, J. L., Jr., Distribution of potassium and sodium between serum and certain extracellular fluids in man. Am. J. Physiol., 1948, 153, 381.

24. Berliner, R. W., Kennedy, T. J., Jr., and Hilton, J. G., Renal mechanisms for the excretion of potassium. Am. J. Physiol., 1950, 162, 348.

25. Elkinton, J. R., and Winkler, A. W., Transfers of intracellular potassium in experimental dehydration. J. Clin. Invest., 1944, 23, 93. 